\title{
Exogenous and endogenous contributions to nitrogen fluxes in the digestive tract of pigs fed a casein diet. III. Recycling of endogenous nitrogen
}

\author{
WB Souffrant $1^{\star}$, A Rérat 2, JP Laplace ${ }^{2^{\star \star}}$, B Darcy-Vrillon 2, \\ R Köhler 1, T Corring 2, G Gebhardt 1
}

\author{
with the technical assistance of F Bernard, ML Jähnichen, \\ B Schneider and F Cointepas
}

\begin{abstract}
1 Karl-Marx-Universität Leipzig, Sektion Tierproduktion und Veterinärmedizin, Wissenschaftsbereich Tierernährungsphysiologie und Futtermittelkunde, G Kühn Str 8, 7022 Leipzig, Germany; 2 Station de Physiologie de la Nutrition, INRA-CRJ, 78352 Jouy-en-Josas Cedex, France
\end{abstract}

(Received 21 January 1993; accepted 24 June 1993)

\begin{abstract}
Summary - The aim of the present study was to measure the incorporation of infused ${ }^{15} \mathrm{~N}$ in blood fractions, urine, digesta, faeces and in the exocrine pancreatic and biliary secretions, in order to estimate the endogenous part of nitrogen in the ileal digesta and in the faeces of pigs fed a casein diet and to calculate the total endogenous nitrogen secretion as well as its recycling in the digestive tract. For $8 \mathrm{~d} 11$ Large White female pigs $(50.1 \pm 1.8 \mathrm{~kg})$ received a continuous infusion of $L-\left[{ }^{15} \mathrm{~N}\right]$ leucine via a catheter in the jugular vein. The ${ }^{15} \mathrm{~N}$-enrichment was measured in several fractions. The ${ }^{15} \mathrm{~N}$ level of the pancreatic juice was higher than that in the biliary secretion, TCA-blood fractions, and urine during the whole experimental period. Using the ${ }^{15} \mathrm{~N}$-isotope dilution method it was found that casein was completely digested up to the terminal ileum and that all the nitrogen in the ileal digesta was of endogenous origin. The total endogenous secretion was estimated at $\approx 11 \mathrm{~g} \mathrm{~N} / \mathrm{d}$. The reabsorption of endogenous nitrogen amounted to $79 \%$ up to the end of the small intestine and $88 \%$ over the whole digestive tract.
\end{abstract}

endogenous nitrogen / intestine / digestion / absorption / pig

Résumé - Contributions exogènes et endogènes aux flux d'azote dans le tube digestif du porc recevant un régime à base de caséine. III. Recyclage de l'azote endogène. Le présent travail a tenté d'estimer la proportion d'azote d'origine endogène dans les digesta iléaux et dans les

\footnotetext{
* Present address: Forschungsbereich Ernährungsphysiologie "Oskar Kellner" des Forschungsinstitutes für die Biologie landwirtschaftlicher Nutztiere, 2500 Rostock, Justus-von-Liebig-Weg 2, Germany. ** Present address: INRA-CRR, Station de Recherches Porcines, 35590 Saint-Gilles, France
} 
fèces de porcs recevant un aliment à base de caséine, de calculer la sécrétion totale d'azote endogène, et d'évaluer son recyclage dans le tube digestif. Onze porcs Large-White femelles $(50,1 \pm 1,8$ $\mathrm{kg}$ ) ont reçu durant 8 jours, grâce à un cathétérisme de la veine jugulaire, une perfusion continue de $\left.L-l^{15} \mathrm{~N}\right]$ leucine. L'enrichissement en ${ }^{15} \mathrm{~N}$ a été mesuré dans différentes fractions sanguines, dans les urines, les digesta, les fèces, ainsi que dans les sécrétions exocrines biliaire et pancréatique. Durant toute la période expérimentale, le taux de ${ }^{15} \mathrm{~N}$ dans le suc pancréatique a été plus élevé que dans la bile, les fractions sanguines séparées par le TCA, ou l'urine. Cette méthode de dilution de l'isotope stable ${ }^{15} \mathrm{~N}$ a permis de montrer que, au niveau de l'iléon terminal, la caséine est déjà complètement digérée et que la totalité de l'azote des digesta est d'origine endogène. La sécrétion endogène totale d'azote a été estimée à environ $11 \mathrm{~g}$ par jour. Ce sont $79 \%$ de cet azote endogène qui ont été réabsorbés avant l'extrémité distale de l'intestin grêle, et $88 \%$ pour la totalité du tube digestif.

\section{azote endogène / intestin / digestion / absorption / porc}

\section{INTRODUCTION}

Several methods can be used to measure protein digestibility and amino acid (AA) absorption in the digestive tract. The most usual method is the balance technique, based on the difference between amounts ingested and excreted at a given section of the gastrointestinal tract (GIT). However, this method leads to underestimation of digestibility as a result of the contribution of endogenous nitrogen $(N)$ and $A A$ in the digesta or faeces.

Rérat et al (1980) used the blood-flow method to measure $A A$ absorption based on the simultaneous determination of the porto-arterial concentration differences and the portal blood-flow rate. This can result in overestimated absorption values for dietary protein and AA due to the additional absorption of endogenous $\mathrm{N}$ and $\mathrm{AA}$, but also to an underestimation as a result of AA uptake by the gut wall.

Quantifying the endogenous proportion of $\mathrm{N}$ in digesta or faeces under protein feeding conditions requires the use of marker substances, such as homoarginine (Hagemeister and Erbersdobler, 1985, 1987 ) or $15 \mathrm{~N}$-labelled $A A$ and proteins (Souffrant, 1991).

The aim of the present investigation was to estimate the endogenous protein in ileal digesta by means of the isotope dilution technique in pigs fed a casein diet. Furthermore, using the results of pancreatic and bile secretion (Corring et al, 1990), of ileal and faecal digestibilities and absorption coefficients (Darcy-Vrillon et al, 1991), we estimated the total endogenous $\mathrm{N}$-secretion and recycling.

\section{MATERIALS AND METHODS}

\section{Animals and experimental design}

Eleven growing Large White female pigs weighing $50.1 \pm 1.8 \mathrm{~kg}$, surgically prepared so that the apparent digestibilities of protein and AA absorption at the ileal (pigs $A$ to $D$ ) and fecal levels (pigs $E$ to $K$ ), and the $N$ and $A A$ appearance in the portal blood (pigs $E$ to $H$ ) (Darcy-Vrillon et al, 1991) could be measured or the exocrine pancreatic and biliary secretions (pigs I to K) (Corring et al, 1990) estimated, were also fitted with permanent catheters in the jugular vein and carotid artery for infusion and blood sampling respectively, and with a permanent urinary catheter.

Following surgery, the animals were housed individually in metabolic cages and adapted to a casein diet (Corring et al, 1990). After recovery, the pigs were used in the different experiments. The N-pool of the animals was labelled by continuous iv infusion of $\mathrm{L}-\left[{ }^{15} \mathrm{~N}\right]$ leucine $\left(95 \%{ }^{15} \mathrm{~N}\right.$ enrichment) via the jugular catheter over an 8-d 
period, according to de Lange et al (1992). A peristaltic pump was used for infusion at a rate of $480 \mathrm{ml} / \mathrm{d}$ sterile saline solution supplying $40 \pm$ $2 \mathrm{mg} L-[15 \mathrm{~N}]$ leucine $/ \mathrm{kg}$ body weight/d.

During the 8-d period the animals received the diet in 2 daily meals (at 9.00 and $16.00 \mathrm{~h}$ ) of $800 \mathrm{~g}$ each diluted in water (1:1). The details of ileal digesta collection, absorption studies, faeces collection or pancreatic juice and bile sampling have been previously described by Corring et al (1990) and Darcy-Vrillon et al (1991). During the infusion period, urine was collected quantitatively via a balloon catheter and a closed urinary drainage system, in order to measure urinary ${ }^{15} \mathrm{~N}$-excretion. Blood and urine samples were taken every $12 \mathrm{~h}$.

\section{Analytical methods}

Heparinized blood (10 $\mathrm{ml}$ ) was immediately centrifuged (1000 g, $10 \mathrm{~min}$ ) after sampling and $6 \mathrm{ml}$ of each blood sample supernatant were mixed with $10 \%$ trichloracetic acid (TCA) and centrifuged (5000 g, $15 \mathrm{~min}$ ). The precipitate was washed twice with $2 \mathrm{ml} \mathrm{10 \%} \mathrm{TCA.} \mathrm{Superna-}$ tants were pooled and the sediment isolated.

The measure ${ }^{15} \mathrm{~N}$-enrichment in all samples (faeces, digesta, urine and the TCA-fractions of blood, bile and pancreatic juice); total $N$ was determined using the Kjeldahl method and titration with $\mathrm{HCl}$. The $\mathrm{NH}_{4} \mathrm{Cl}$ solution obtained was taken directly for ${ }^{15} \mathrm{~N}$-analysis with an Isonitromat emission spectrometer according to the procedure described by Faust (1967).

\section{Calculations}

To ensure that the ${ }^{15} \mathrm{~N}$-enrichment of total $\mathrm{N}$ in the TCA-soluble blood fraction and other substances reached a plateau at the end of the infusion period, the whole set of individual data was processed by the SAS system non-linear regression procedure using the following model:

$$
y=A\left(1-e^{-b x}\right)
$$

The endogenous part of $\mathrm{N}$ in the ileal digesta and faeces was determined in the pooled samples of the last day of the infusion period via the ${ }^{15} \mathrm{~N}$-isotope dilution method (Souffrant et al,
1981). The contribution of endogenous to total $N$ in digesta or faeces can be calculated from the ratio between the ${ }^{15} \mathrm{~N}$-enrichment of total $\mathrm{N}$ in the ileal digesta or faeces and the $15 \mathrm{~N}$ enrichment of total $\mathrm{N}$ in the TCA-soluble blood fraction, according to the following formula:

$$
N_{E}=N_{D / F} \cdot \frac{{ }^{15} N_{D / F}}{{ }^{15} N_{B}}
$$

where $N_{E}$ is the quantity of endogenous $N ; N_{D / F}$ is the quantity of total $N$ in digesta or faeces ; ${ }^{15} N_{O / F}$ is the percentage of ${ }^{15} \mathrm{~N}$-enrichment of total $N$ in digesta or faeces ; and ${ }^{15} N_{B}$ the percentage of $15 \mathrm{~N}$-enrichment of total $N$ in the TCAsoluble blood fraction.

\section{RESULTS AND DISCUSSION}

\section{Time-course of ${ }^{15} \mathrm{~N}$-labelling of blood, pancreatic juice, bile, urine, digesta and faeces}

The ${ }^{15} \mathrm{~N}$-isotope dilution technique seems to be one of the most valid methods for determining the recovery of endogenous $N$ in the digesta and faeces in pigs fed proteincontaining diets (Souffrant et al, 1981; de Lange et al, 1990, 1992; Huisman et al, 1992). The principle of using the $15 \mathrm{~N}$ isotope dilution method to differentiate between endogenous protein and nondigested dietary protein in the digestive tract is based on the change of the isotopic ratios in digesta or faeces. Such changes occur during passage through the GIT when $15 \mathrm{~N}$-labelled proteins are given or when the $\mathrm{N}$-pool of the animals is labelled with $15 \mathrm{~N}$ and when unlabelled proteins are fed (Souffrant et al, 1982). The latter technique was used in the present experiments: in order to determine the course of $15 \mathrm{~N}$-labelling in the excretion products, the $15 \mathrm{~N}$-enrichment of urine and ileal digesta was measured every $12 \mathrm{~h}$, and that of faeces only once a day over the whole in- 
fusion period. The incorporation of infused $15 \mathrm{~N}$ into pancreatic juice and bile was monitored at 2-h intervals and every $12 \mathrm{~h}$ in blood fractions. Calculated on data of all animals $(A$ to $K$ ) used in the different parts of the experiment, the ${ }^{15} \mathrm{~N}$-enrichment in urine was on each occasion higher than in the TCA-soluble plasma but did not reach the calculated plateau value $(0.4587$ atom-\%-excess) at the end of the infusion period (fig 1). In contrast, the $15 \mathrm{~N}$ enrichment of the TCA-soluble plasma nearly reached the calculated plateau value $(0.2687$ atom-\%-excess) at the end of the infusion period. Figure 2 shows the time-course of $15 \mathrm{~N}$-enrichment in bile and pancreatic juice calculated on data of animals I to $\mathrm{K}$. The ${ }^{15} \mathrm{~N}$-enrichment in bile increased slowly and did not reach the calculated plateau value $(0.2567$ atom-\%excess) at the end of the infusion period. In pancreatic juice $15 \mathrm{~N}$-enrichment increased rapidly and reached the calculated plateau value $(0.4224$ atom-\%-excess) before the end of the infusion period. However these calculations of the $15 \mathrm{~N}$ enrichment overall time-course would only have had true meaning if all experimental conditions had been identical for all animals. The strong constraints of the experimental design over the 3 parts of the experiment led to differences between the

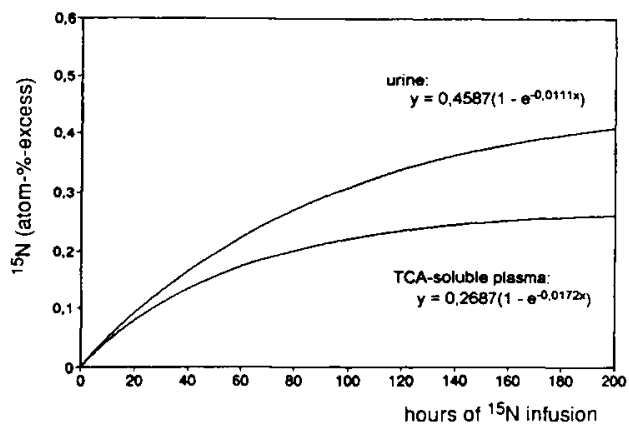

Fig 1. Overall time-course of ${ }^{15} \mathrm{~N}$-enrichment in urine and TCA-soluble plasma fraction, calculated on data of all animals ( $A$ to $K$ ). animals in surgical treatment, ${ }^{15} \mathrm{~N}$-infusion, $\mathrm{N}$-intake, $\mathrm{N}$-utilization and daily gain. Therefore the data in figures 1 and 2 only provide a general view of the ${ }^{15} \mathrm{~N}$-labelling. The individual data must be used to characterize the time-course and to calculate the amounts of endogenous $\mathrm{N}$ in digesta or faeces.

For example, figure 3 shows the timecourse of $15 \mathrm{~N}$-enrichment of excretion products, as compared to that of TCAsoluble fraction of plasma, in the case of pig $\mathrm{B}$ considered as representative of the other animals. The ${ }^{15} \mathrm{~N}$-enrichment of urine rose rapidly during the first 3-d period, then increased slowly and tended to reach a plateau during the last few $d$ of infusion. In digesta and faeces the increase of $15 \mathrm{~N}$ enrichment was much slower than in urine. While it took $3 \mathrm{~d}$ for ${ }^{15} \mathrm{~N}$-labelling in digesta to reach the same enrichment as the TCA-soluble fraction of plasma $7 \mathrm{~d}$ were required before the same level was reached in the faeces, the passage rate being slower in the large intestine. The $15 \mathrm{~N}$-enrichment in the TCA-soluble fraction of plasma increased rapidly within the first $24 \mathrm{~h}$ and came to a plateau at the end of the infusion period. A similar $15 \mathrm{~N}$ enrichment time-course has been reported by de Lange et al (1990) using the same technique.

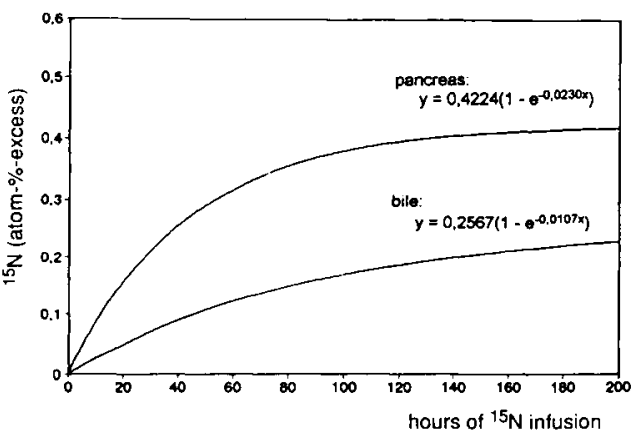

Fig 2. Overall time-course of $15 \mathrm{~N}$-enrichment in bile and pancreatic juice, calculated on data of animals I to $\mathrm{K}$. 


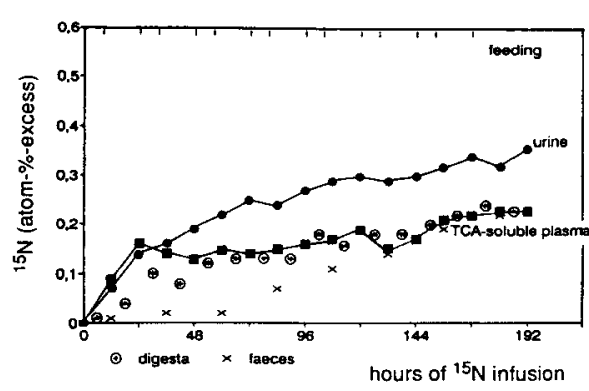

Fig 3. Individual time-course of $15 \mathrm{~N}$-enrichment in urine, ileal digesta, faeces and TCA-soluble plasma fraction of pig $B$.

The course of ${ }^{15} \mathrm{~N}$-enrichment in different blood fractions is illustrated in figure 4. The lowest $15 \mathrm{~N}$-incorporation was found in the blood cells, ie the pellet after centrifugation of heparinized blood. As in figure 3 , ${ }^{15} \mathrm{~N}$-concentration in the TCA-soluble fraction of plasma increased rapidly at the beginning of the infusion period, and reached an enrichment plateau after $4 \mathrm{~d}$. In contrast, the $15 \mathrm{~N}$-enrichment of the TCAprecipitable fraction of plasma, ie the plasma protein, increased continuously during the infusion period and did not reach the $15 \mathrm{~N}$-enrichment of TCA-soluble plasma fraction.

Figure 5 shows the measured $15 \mathrm{~N}$ enrichment and the corresponding calculated time-course of ${ }^{15} \mathrm{~N}$-enrichment of total $\mathrm{N}$ in bile and pancreatic juice in comparison to the TCA-soluble plasma fraction. The time-course of $15 \mathrm{~N}$-enrichment in bile throughout the infusion period was similar to that of the TCA-soluble plasma fraction, while $15 \mathrm{~N}$-enrichment in the pancreatic juice reached twice that of the TCA-soluble plasma fraction at the end of the infusion period. In addition it can be noted that $15 \mathrm{~N}$ enrichment in urine reached a plateau which was similar to that of the TCAsoluble plasma fraction. All these calculated time-courses of $15 \mathrm{~N}$-enrichment indicate that the plateaus were reached at - or before - the end of the 8-d infusion period, in agreement with previous experiments ( $\mathrm{Hu}$ isman et al, 1992) based on 7 to 11-d infusions. To characterize ${ }^{15} \mathrm{~N}$-incorporation into pancreatic juice and bile, $15 \mathrm{~N}$ enrichment of their TCA-soluble and TCAprecipitable fractions were both measured. These are shown for pancreactic juice in figure 6 . As reported by Corring et al (1990), the TCA-soluble $\mathrm{N}$ represents only

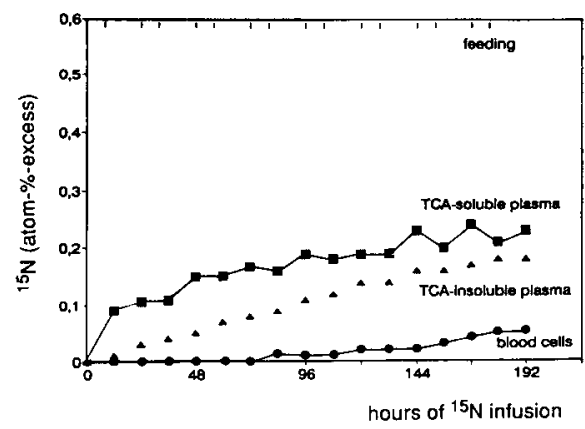

Fig 4. Individual time-course of ${ }^{15} \mathrm{~N}$-enrichment in the different blood fractions of pig $\mathrm{I}$.

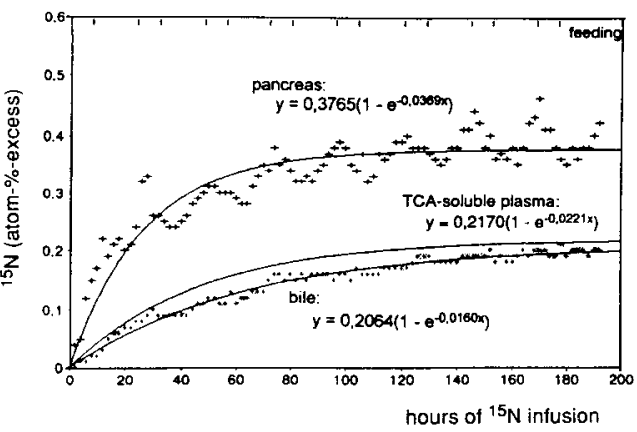

Fig 5. Observed and calculated time-course of ${ }^{15} \mathrm{~N}$-enrichment in bile and pancreatic juice of pig I, compared to the calculated time-course in its TCA-soluble plasma fraction. 
$12 \%$ of the total $\mathrm{N}$ and comes mainly from free $A A$, amino-sugars, and amides, especially urea. The $15 \mathrm{~N}$-enrichment of this fraction seems to be very sensitive to variations in $15 \mathrm{~N}$-enrichment of the precursor pool, which depends on the proportion between absorbed unlabelled exogenous $\mathrm{N}$ and the constant flow of infused $15 \mathrm{~N}$. The $15 \mathrm{~N}$-enrichment of this fraction increased continuously over the experimental period with strongly oscillating variations and tended to reach a plateau at the end. On the other hand, ${ }^{15} \mathrm{~N}$-enrichment of the TCA-insoluble fraction of pancreatic juice was higher with less marked oscillations. The $15 \mathrm{~N}$-enrichment increased within the first $24 \mathrm{~h}$ and afterwards seemed to follow the feeding pattern. After feeding, when absorption of unlabelled exogenous $\mathrm{N}$ began, the ${ }^{15} \mathrm{~N}$-level decreased, then rose again at the end of the absorption phase, because of the constant infusion. The influence of feeding has to be further demonstrated by a specific study. Nevertheless, our results support the observation that $A A$ derived from exogenous proteins are absorbed and reappear in the GIT via pancreatic secretion within a short time after feeding (Simon et al, 1983). Because the TCA-precipitable $\mathrm{N}$ constitutes the main part of total $\mathrm{N}$ in pancreatic juice,

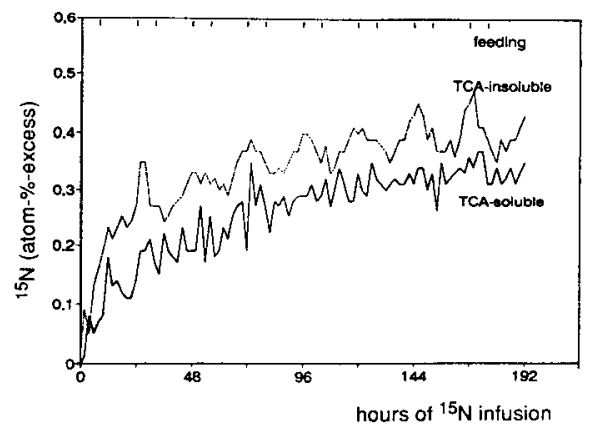

Fig 6. Observed time-course of $15 \mathrm{~N}$-enrichment in the TCA-fractions of pancreatic juice of pig 1 . such a rhythmic variation can also be observed in the $15 \mathrm{~N}$-enrichment of total pancreatic $\mathrm{N}$ (fig 5). The time-course of $15 \mathrm{~N}$ incorporation in both fractions of bile is shown in figure 7 . The increase of $15 \mathrm{~N}$ enrichment in bile was similar in both fractions, but was much lower than in the pancreatic secretion. It also appeared to be poorly affected by the $\mathrm{N}$-fluxes in comparison with pancreatic secretion. During the first $36 \mathrm{~h}$ of infusion, the $15 \mathrm{~N}$-enrichment of TCA-soluble $\mathrm{N}$ was slightly higher than that of the TCA-insoluble part.

\section{Endogenous $N$ assessment in digesta and faeces}

Using the ${ }^{15} \mathrm{~N}$-isotope dilution technique, the endogenous part of $N$ was calculated according to the above-mentioned formula. A critical aspect of this method is that regarding choice of a reference substance, whole ${ }^{15} \mathrm{~N}$-enrichment reflects the average labelling of the total endogenous $\mathrm{N}$ secreted into the GIT. Endogenous $\mathrm{N}$ originates from different sources and it is impossible to estimate the ${ }^{15} \mathrm{~N}$-enrichment of all the different precursor pools and calculate an appropriate average without knowing their contribution to the total endogenous $\mathrm{N}$ -

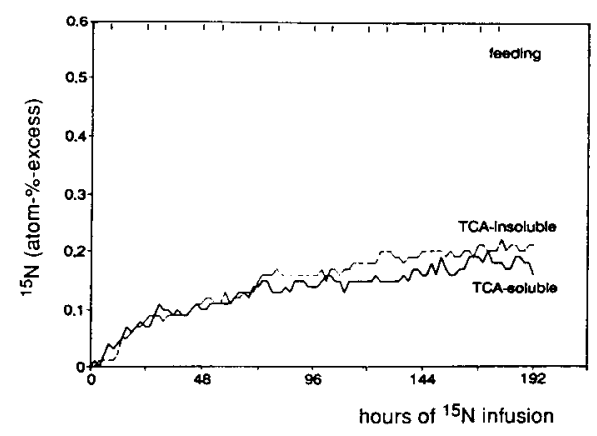

Fig 7. Observed time-course of $15 \mathrm{~N}$-enrichment in the TCA-fractions of bile of pig 1 . 
secretion. Therefore, the ${ }^{15} \mathrm{~N}$-enrichment of a substance which is easy to measure and which approximately reflects the $\mathrm{N}$ pool of the body should be used. Both urine and blood are commonly-used indicators. However, as ${ }^{15} \mathrm{~N}$-labelling of urine is affected by several factors, such as the relationship between $\mathrm{N}$-intake and infused $\mathrm{N}$ and the intermediate utilization of exogenous $N$, it should not be used as a reference for the calculation of endogenous nitrogen in chyme or faeces. As pointed out by Herrmann et al (1986), the TCA-soluble blood plasma fraction appears to be the most appropriate reference for the $15 \mathrm{~N}$ enrichment of endogenous $\mathrm{N}$. This fraction reflects the $A A$ pool required for protein synthesis, and thus for the formation of endogenous proteins, irrespective whether it is derived from intermediary protein conversion or has been supplied by absorption. The urea - present in the TCAsoluble plasma fraction - is also an important component of endogenous $\mathrm{N}$ secretion (Rérat et al, 1979). Rérat and Buraczewska (1986) estimated that the daily endogenous secretion of urea in the GIT of pigs averages $6 \mathrm{~g} \mathrm{~N}$.

Based on these arguments, the TCAsoluble fraction of blood plasma was used in the present investigation to assess the endogenous contribution to the $\mathrm{N}$ in digesta and faeces. Though well founded, this reference to TCA-soluble plasma fraction remains approximative. Indeed, the $15 \mathrm{~N}$ enrichment of pancreatic juice was higher than that of the TCA-soluble plasma fraction. Pancreatic juice constitutes only one part of endogenous $\mathrm{N}$ secretion but is certainly that with the highest $15 \mathrm{~N}$-enrichment because of its high turnover. On the contrary, the $15 \mathrm{~N}$-enrichment of the other endogenous $\mathrm{N}$ sources, such as saliva, gastric juice, intestinal secretions, desquamations and bacteria, is assumed to be lower than that of the TCA-soluble fraction of blood plasma due to the lower turnover rate of these source and/or the direct use of absorbed unlabelled dietary AA. The ${ }^{15} \mathrm{~N}$-enrichment found in bile supports this assumption.

In all pigs ( $A$ to $K$ ) the ${ }^{15} \mathrm{~N}$-enrichment in ileal digesta and/or faeces collected on the last day of infusion was the same as in their respective TCA-soluble plasma fraction. Thus it can be concluded that the whole $\mathrm{N}$ excreted in ileal digesta and faeces was of endogenous origin and that dietary casein had been digested quantitatively before the terminal ileum. Similar results have been reported by Hagemeister and Erbersdobler (1985, 1987). They investigated the ileal digestibility of casein in Götting miniature pigs. The homoarginine method also enabled them to demonstrate that the true precaecal digestibility was $\approx 99.5 \%$ and that $>90 \%$ of the $\mathrm{N}$ found in the digesta at the end of the small intestine was of endogenous origin. For heatdamaged casein, the authors found a reduced ileal absorption of 93 to $97 \%$.

\section{Recycling of endogenous $N$}

After our preliminary approach (Souffrant et al, 1986), the total daily endogenous $\mathrm{N}$ secretion and the reabsorption of endogenous $N$ in the GIT were estimated again for the data published in our first and second reports (Corring et al, 1990; Darcy-Vrillon et al, 1991) and those given in the present paper. The various $\mathrm{N}$ fluxes are summarized in figure 8 where only the measured values can be given as mean and SEM while calculated values are given as an estimate without SEM.

The average amount of $\mathrm{N}$ ingested on the day of collection was $23.6 \pm 2.1 \mathrm{~g}$, whereas $2.2 \pm 0.3$ and $1.3 \pm 0.1 \mathrm{~g} \mathrm{~N}$ were found in ileal digesta and faeces respectively. Using the blood flow method and measuring the porto-arterial concentration 


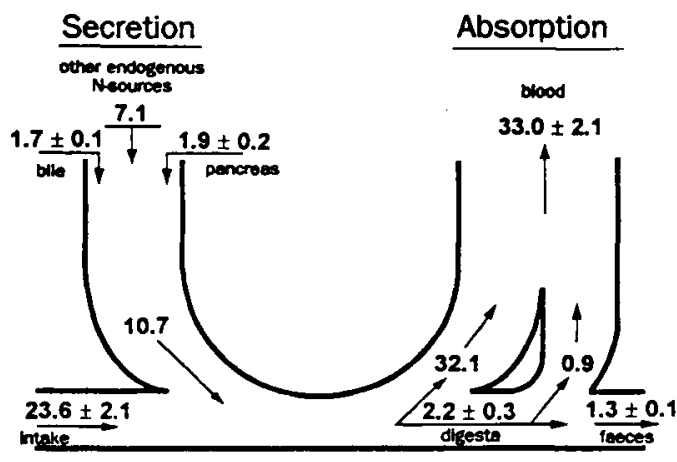

Fig 8. Diagram of the main $\mathrm{N}$-fluxes in the gastrointestinal-tract of pigs, evidencing $\mathrm{N}$ recycling (as $\mathrm{g} \mathrm{N}$ per day). Measured values are given as mean \pm SEM. Calculated values are given as an estimate.

differences, a daily total $\mathrm{N}$-absorption of $33.0 \pm 2.1 \mathrm{~g}$ was found, representing $140 \%$ of $\mathrm{N}$-intake. According to the $15 \mathrm{~N}$ isotope dilution technique, ileal protein digestibility was $100 \%$, and $N$ contained in the ileal digesta and faeces was exclusively of endogenous origin. Thus, the difference between the digested $23.6 \mathrm{~g}$ and the absorbed $33.0 \mathrm{~g}$ of nitrogen must correspond to reabsorbed endogenous $N$. The total daily endogenous $\mathrm{N}$-secretion, ie the sum of reabsorbed $N$ and faecal $N$ amounted to $10.7 \mathrm{~g}$. This is less than the values reported by Low (1982) and Krawielitzki et al (1990), probably because of the low protein intake $(23.6 \mathrm{~g})$ in our pigs. While Low (1982) calculated a daily endogenous secretion of $18.1 \mathrm{~g}$ for a daily $\mathrm{N}$ intake of $40 \mathrm{~g}$, Krawielitzki et al (1990) found $16.1 \mathrm{~g}$ for a daily $\mathrm{N}$-intake of $35 \mathrm{~g}$. In the present experiments the daily amount of endogenous $\mathrm{N}$-secretion in the intestinal lumen was $1.9 \pm 0.2 \mathrm{~g}$ via pancreatic secretion and $1.7 \pm 0.1 \mathrm{~g}$ through bile secretion (Corring et al, 1990). Accordingly, the pancreatic and bile secretions represented only 18 and $16 \%$ respectively of the total endogenous $\mathrm{N}$-secretion, and $7.1 \mathrm{~g} \mathrm{~N}$ came from other endogenous $\mathrm{N}$-sources. Values for pancreatic and bile $\mathrm{N}$-secretion in pigs have been reported by many authors and both varied between 1 and $3 \mathrm{~g}$ $\mathrm{N} / \mathrm{d}$, depending on diet composition (Corring and Jung, 1972; Sambrook, 1978; Juste et al, 1979; Partridge et al, 1982; Ozimek et al, 1985; Zebrowska, 1985; Souffrant et al, 1985). For the other endogenous $\mathrm{N}$-sources, not many values are available. In pig experiments with $15 \mathrm{~N}$ labelled wheat, Zebrowska et al (1982) measured $3.3 \mathrm{~g}$ endogenous $\mathrm{N} / \mathrm{d}$ in mixed secretions of saliva and gastric juice. Buraczewska (1979) found a total endogenous $\mathrm{N}$-secretion from the small intestine of $\approx 14.4 \mathrm{~g} / \mathrm{d}$.

For reabsorption of endogenous $\mathrm{N}$ or $A A$ in pigs not so many values are available. In experiments with protein-free diets Rérat et al (1988) found a reabsorption of $2 \mathrm{~g} \mathrm{AA} / \mathrm{h}$. In the present studies the reabsorption of endogenous $\mathrm{N}$, calculated from the total daily secretion $(10.7 \mathrm{~g})$ and the reabsorbed $\mathrm{N}(9.4 \mathrm{~g}$ up to the end of the GIT), amounted to $88 \%$. The reabsorption up to the end of the small intestine, calculated from the $0.9 \mathrm{~g}$ endogenous $\mathrm{N}$ reabsorbed in the large intestine, amounted to $79 \%$ of total endogenous $\mathrm{N}$-secretion. Similar results have been reported by Krawielitzki et al (1990). In their studies they found a reabsorption for endogenous $N$ up to the end of the terminal ileum and throughout the whole digestive tract of 73 and $90 \%$, respectively. According to Low (1982) the reabsorption of endogenous $N$ at the end of the digestive tract only amounted to $78 \%$.

\section{CONCLUSION}

In conclusion, under the present experimental conditions, the estimate of the total 
endogenous $\mathrm{N}$-secretion was much higher than the residual endogenous $\mathrm{N}$-amount measured in the ileum, thus indicating an extensive reabsorption throughout the small intestine. Further studies are needed to determine the endogenous $\mathrm{N}$-sources separately. Moreover, the pig model using the $15 \mathrm{~N}$ isotope dilution technique combined with methods of experimental surgery might be used to extend the present data on endogenous $N$ recycling to other feeding conditions.

\section{REFERENCES}

Buraczewska $L$ (1979) Secretion of nitrogenous compounds into the small intestine of pigs. In: Current Concepts of Digestion and $A b$ sorption in Pigs (Low AG, Partridge IG, eds) NIRD, HRI, Ayr, Tech Bull, 151-153

Corring T, Jung J (1972) The amino acid composition of pig pancreatic juice. Nutr Rep Int 6 , 187-190

Corring T, Souffrant WB, Darcy-Vrillon B, Gebhardt G, Laplace JP, Rérat A (1990) Exogenous and endogenous contribution to nitrogen fluxes in the digestive tract of pigs fed a casein diet. 1. Contributions of nitrogen from the exocrine pancreatic secretion and the bile. Reprod Nutr Dev 30, 717-722

de Lange CFM, Souffrant WB, Sauer WC (1990) Real ileal protein and amino acid digestibilities in feedstuffs for growing pigs as determined with the ${ }^{15} \mathrm{~N}$-isotope dilution technique. J Anim Sci 68, 409-418

de Lange CFM, Sauer WC, Souffrant WB, Lien KA (1992) ${ }^{15} \mathrm{~N}$-leucine and ${ }^{15} \mathrm{~N}$-isoleucine isotope dilution technique versus the $15 \mathrm{~N}$ isotope dilution technique for determining the recovery of endogenous protein and amino acids in digesta collected from the distal ileum in pigs. J Anim Sci 70, 1848-1856

Darcy-Vrillon B, Souffrant WB, Laplace JP, Rérat $A$, Corring $T$, Vaugelade $P$, Gebhardt $G$, Köhler R (1991) Exogenous and endogenous contribution to nitrogen fluxes in the digestive tract of pigs fed a casein diet. 2. Ileal and faecal digestibilities and absorption of amino acids. Reprod Nutr Dev 31, 561-573
Faust $\mathrm{H}$ (1967) Probenchemie ${ }^{15 \mathrm{~N}}$-markierter Stickstoffverbindungen im Makro- bis Nanomolbereich für die emissionspektrometrische Isotopenanalyse. Isotropenpraxis 3, 100-104

Hagemeister H, Erbersdobler H (1985) Chemical labelling of dietary protein by transformation of lysine to homoarginine: a new technique to follow intestinal digestion and absorption. Proc Nutr Soc 44, 133A

Hagemeister H, Erbersdobler H (1987) Messung der präzäkalen Verdaulichkeit von Protein mit der Homoarginin-Methode. Arch Tierernähr 37, 451-452

Herrmann U, Krawielitzki K, Smulikowska S, Schadereit R (1986) Zur Bestimmung des endogenen Stickstoffes im Kot mit Hilfe der Isotopentechnick. Arch Tierernähr 36, 857-865

Huisman J, Heinz $T$, von der Poel AFB, van Leeuwen $P$, Souffrant WB, Verstegen MWA (1992) True protein digestibility and amounts of endogenous protein measured with the ${ }^{15} \mathrm{~N}$-dilution technique in piglets fed on peas (Pisum sativum) and common beans (Phaseolus vulgaris). Br J Nutr 68, 101-110

Juste C, Corring T, Breant $P$ (1979) Excretion biliaire chez le porc : niveau et réponse au repas. Ann Biol Anim Biochim Biophys 19, 79-90

Krawielitzki K, Zebrowska T, Schadereit R, Kowalczyk J, Wünsche J, Herrmann U (1990) Determining of nitrogen absorption and nitrogen secretion in different sections of the pig's intestine by digesta exchange between ${ }^{15} \mathrm{~N}$ labelled and unlabelled animals. Arch Anim Nutr 40, 25-37

Low AG (1982) Endogenous nitrogen evaluation from absorption studies. In: Physiologie Digestive Chez le Porc (Laplace JP, Corring T, Rérat A, eds) Colloq INRA No 12, 187-198

Ozimek L, Sauer WC, Ozimek G (1985) The response of the secretion and activity of pancreatic enzymes to the quality and quantity of fat. In: Digestive Physiology in the Pig (Just $A$, Jorgensen $H$, Fernandez JA, eds) Copenhagen, No 580, 146-148

Partridge IG, Low AG, Sambrook IE, Corring $T$ (1982) The influence of diet on the exocrine pancreatic secretion of growing pigs. $\mathrm{Br} J$ Nutr 48, 137-143

Rérat $A$, Lisoprawski $C$, Vaissade $P$, Vaugelade $P$ (1979) Métabolisme de l'urée dans le tube digestif du porc: données préliminaires quantitatives et qualitatives. Bull Acad Vet Fr 52, 333-346 
Rérat A, Vaugelade P, Villiers PA (1980) A new method for measuring the absorption of nutrients in the pig: critical examination. In: Current Concepts of Digestion and Absorption in Pigs (Low AG, Partridge IG, eds) NIRD, HRI, Ayr, Tech Bull 3, 177-214

Rérat A, Buraczewska L (1986) Postprandial quantitative kinetics of urea and ammonia nitrogen exchanges between the digestive tract and the portal blood in conscious pigs receiving a diet with or without urea. Arch Tierernähr 36, 252-269

Rérat A, Vaissade $P$, Vaugelade $P$ (1988) Quantitative measurement of endogenous amino acid absorption in unanaesthetized pigs. Arch Tierernähr 38, 463-479

Sambrook IE (1978) Flow and composition of bile in growing pigs. Proc Nutr Soc 37, 84A

Simon $O$, Zebrowska $T$, Bergner $H$, Münchmeyer R (1983) Investigations on the pancreatic and stomach secretions in pigs by means of continuous infusion of ${ }^{14} \mathrm{C}$ amino acids. Arch Tierernähr 33, 9-22

Souffrant WB, Köhler R, Matkowitz R, Gebhardt G, Schmandtke H (1981) Ernährungsphysiologische Untersuchungen an Schweinen zur Beurteilung von modifizierten Proteinen. Arch Tierernähr 31, 675-683

Souffrant WB, Köhler R, Gebhardt G (1982) Détermination de l'azote endogène dans les contenus digestifs par la technique isotopique (15N). In: Physiologie Digestive Chez le Porc (Laplace JP, Corring T, Rérat A, eds) Colloq INRA, No 12, 175-187

Souffrant WB, Schumann B, Gebhardt G, Matkowitz $\mathrm{R}$ (1985) Untersuchungen zur exokrinen Pankreassekretion beim Schwein nach Verfütterung von Sojaextraktionsschrot. Arch Tierernähr 35, 383-389

Souffrant WB, Darcy-Vrillon B, Corring T, Laplace JP, Köhler R, Gebhardt G, Rérat A (1986) Recycling of endogenous nitrogen in pig (preliminary results of a collaborative study). Arch Tierernähr 36, 269-274

Souffrant WB (1991) Endogenous nitrogen losses during digestion in pigs. In: Digestive Physiology in Pigs (Verstegen MWA, Huisman J, den Hartog LA, eds) Pudoc, Wageningen, 147-166

Zebrowska T (1985) The influence of level and source of fibre in the diet on the exocrine pancreatic secretion in growing pigs. In: $D i-$ gestive Physiology in the Pig (Just A, Jorgensen $\mathrm{H}$, Fernandez JA, eds) Copenhagen, No $580,152-154$

Zebrowska T, Simon O, Münchmeyer R, Bergner $H$, Zebrowska $H$ (1982) Untersuchungen zur Sekretion und Resorption von Aminosäuren im Magen wachsender Schweine. Arch Tierernähr 32, 703-710 